\section{Australian Journal of \\ Crop Science}

AJCS 14(12):1991-1998 (2020)

doi: 10.21475/ajcs.20.14.12.2871

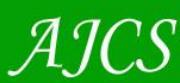

ISSN:1835-2707

\title{
Quality and antioxidant activity of 'Isabel Precoce' grapes installed on different training systems and rootstocks in warmer seasons in a tropical semi-arid region
}

\author{
Rayssa Ribeiro da Costa ${ }^{1}$, Talita de Oliveira Ferreira ${ }^{2}$, Antônio Augusto Marques Rodrigues ${ }^{1}$, Eugênio \\ Ribeiro de Andrade $\mathrm{Neto}^{3}$, Maria Auxiliadora Coêlho de Lima* ${ }^{4}$
}

\author{
${ }^{1}$ Universidade Federal da Paraíba, PO Box 66, Zip Code 58397-000, Areia, Paraiba, Brazil \\ ${ }^{2}$ Universidade Federal do Vale do São Francisco, BR 407, km 119, Zip Code 56300-990, Petrolina, Pernambuco, Brazil \\ ${ }^{3}$ Universidade de Pernambuco, BR 203, km 2, Zip Code 56328-900, Petrolina, Pernambuco, Brazil \\ ${ }^{4}$ Embrapa Semiárido, PO Box 23, Zip Code 56302-970, Petrolina, Pernambuco, Brazil
}

*Corresponding author: auxiliadora.lima@embrapa.br

\begin{abstract}
Production system and environmental factors might cause changes in grapevine physiology, affecting grape yield, quality, phenolic composition, and antioxidant potential. The aim of this study was to characterize the quality and antioxidant potential of 'Isabel Precoce' grapes on different training systems and rootstocks in warmer seasons, in tropical conditions. Experimental design was in randomized blocks, in sub-subplots through time and four replicates. Three training systems (overhead trellis, lyre and vertical shoot positioning - VSP) and two rootstocks ('IAC 572' and 'IAC 766') were studied in the production cycles from July to October, 2017 and from July to October, 2018 in the Submedium of São Francisco Valley. Berry weight; cluster weight; color attributes; berry resistance to compression (COMP); titratable acidity; soluble solids; total soluble sugars (TSS); yellow flavonoids; total anthocyanins; total extractable polyphenols and antioxidant activity by $\mathrm{ABTS}^{\bullet+}$ and $\mathrm{DPPH}^{\bullet}$ free radical capture methods were analyzed. Lyre and VSP resulted on increases of $6 \%$ and $17 \%$ in berry weight and COMP, respectively. Moreover, differences between production cycles were more intense for both variables. In production cycle from July to October 2017, lyre and VSP

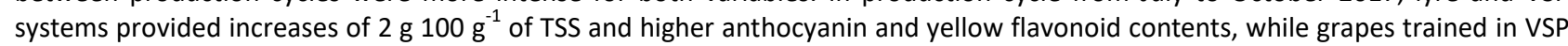

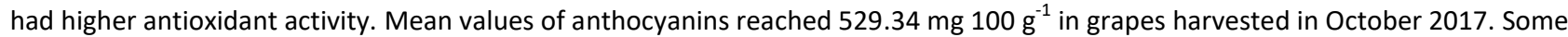
grape quality and chemical components showed high variation in warmer seasons of sucessive years, according to training system or rootstock and their combinations.
\end{abstract}

Keywords: Grapes for juice; phenolic compounds; tropical vitiviniculture; vineyard management; Vitis labrusca L.

Abbreviations: AA_antioxidant activity, $\mathrm{ABTS}^{\bullet+}{ }_{-} 2,2^{\prime}$-azino-bis(3-ethyllbenzothiazoline-6-sulfonic acid, ANT_total anthocyanins content, BW_berry weight, C1_production cycle from July to October, 2017, C2_production cycle from July to October, 2018, COMP_berry resistance to compression, CV_coefficient of variation, CW_cluster weight, DPPH_2,2-diphenil-1-pycril-hydrazil, FLAV_yellow flavonoids content, L_luminosity, OTS_overhead trellis system, PCA_principal component analysis, R1_rootstock 'IAC 572', R2_rootstock 'IAC 766', SSC_soluble solids content, TA_titratable acidity, TEP_total extractable polyphenols content, TSS_total soluble sugars content, VSP_vertical shoot positioning.

\section{Introduction}

The grape juice-making sector in the Brazilian tropical semiarid primarily cultivates Vitis labrusca L. and hybrids. The major cultivars are 'Isabel Precoce', 'BRS Cora', 'BRS Violeta', and 'BRS Magna' (Leão et al., 2018). Isabel Precoce grapes constitute the basis of the most juices produced in Brazil, with its color limitation compensated in blends with recognizably teinturier cultivars.

Under tropical semi-arid climate, the grapevine does not have the dormancy stage and develops continuously throughout the year. Thus, it is possible to find plants at different phenological phases at the same time and in the same production area. It is also possible to obtain two harvests per year (Leão et al., 2016), which causes variations in grape composition and quality between harvests. However, the extension of the variations is not properly characterized and the industries do not have prior and precise support for decisions on the proportions of cultivars in the blends.

The characteristics of the juice are closely related with grape quality, which in turn, is also intimately related with grapevine management (Miele and Rizzon, 2017). Therefore, management strategies associated to the choice of training system and rootstock might increase not only grapevine vegetative and productive growth but also grape quality and composition, including its antioxidant potential. Training systems might affect grapevine physiology via a suitable exposure to solar radiation, which provides a desirable microclimate for clusters (Souza et al., 2015; Hickey et al., 2018). On the other hand, rootstocks affect the duration of phenological stages, canopy structure, and fruit growth, yield, and quality (Bascuñán-Godoy et al., 2017). The adequate selection of training systems and rootstocks might 
increase synthesis of compounds. This can add value to fresh grapes and their products. The phenolics are chemical compounds intensively influenced by the production factors as well as by the stresses resulting from the high temperatures and solar radiation in the semi-arid climate. These compounds are directly associated with the antioxidant potential in grapes.

The aim of this study was to characterize the quality and antioxidant potential of 'Isabel Precoce' grapes on different training systems and rootstocks in warmer seasons in tropical conditions.

\section{Results and Discussion}

\section{Berry quality}

Grapevines are trellised to a certain training systems and may undergo anatomic and physiological changes compared to their self-regulation mechanisms, which direct their reserves to vigor or fruiting, depending on the needs (Bem et al., 2015). The nature and intensity of such changes depend on the training system adopted and might explain variations in quality components, which are also influenced by other management factors, particularly rootstock.

Data revealed that cluster weight (CW) does not have normal distribution. The highest values of $\mathrm{CW}$ were observed in the second half of 2018 (cycle 2), with variation ranging from $96.67 \mathrm{~g}$ to $130.32 \mathrm{~g}$, in plants trained to OTS and rootstock ' $I A C$ 766', and in those trained to lyre and rootstock 'IAC 766', respectively (Table 1 ). In the second half of 2017 (cycle 1), CW varied from $41.74 \mathrm{~g}$ to $87.29 \mathrm{~g}$ in plants trained to VSP and rootstock 'IAC 766' and plants trained to OTS with rootstock 'IAC 766 ', respectively.

Cluster and berry weight are indicators of yield related to grapevine flowering and fruiting phases, which might be affected by temperature, solar radiation, relative air humidity, rainfall, and the genetic load of the cultivar (Leão et al., 2018; Silva et al., 2018). The number of flowers in anthesis represents the maximum yield potential, even if many flowers are not fertilized. It is worth noting that the period ranging from full flowering to early ripening is the longest and with the highest thermal requirement for the grapevine. Therefore, the occurrence of moderate rains thorough this phase favors the complete formation of the flower, fertilization, and berry formation (Duchêne, 2016) in non-irrigated vineyards. The concurrence of rainfall in August 2017 with the full flowering period of the grapevine resulted in flowers drop and, as a consequence, the lowest CW observed in cycle 1.

Berry weight (BW) was affected by the individual effects of rootstocks, training systems, and productive cycles. The highest BW $(2.44 \mathrm{~g})$ was observed in plants grafted onto rootstock 'IAC 766' (Table 2). These results might be related to the different vigor provided by rootstocks, as 'IAC 572' is more vigorous than 'IAC 766'. Particularly in soils with low nutrient availability, more vigorous rootstocks have higher ability to absorb and translocate, which boosts grapevine performance. On the other hand, under optimal climate and soil conditions, vigorous rootstocks might lead to excessive vegetative growth, negatively affecting productive traits (Silva et al., 2018). This might have occurred in the present study. Training systems lyre and VSP provided the highest BW $(2.62 \mathrm{~g})$, as the second productive cycle evaluated (Table 3). During carbohydrate accumulation phase, increase in BW and sugar accumulation of fruits was observed (Rienth et al., 2014). Since this accumulation increases under higher solar radiation, as registered in cycle 2 (Table 4), lyre and VSP, together with less vigorous rootstock, possibly enabled a higher interception of solar radiation, leading to a higher accumulation of carbohydrates and increasing BW in cycle 2 . Higher carbohydrate content also stimulates higher water input in the cells due to osmotic potential gradient (Nikinmaa et al. 2012), contributing with the increased weight of these berries.

Berry resistance to compression (COMP) was affected by training systems and productive cycles, with VSP and lyre providing the lowest values, as well as cycle 2 (Table 3 ). With VSP, grapevine shoots are directed upwards through a vertical and narrow curtain, with the fruiting zone below, while lyre uses large lines and open canopy, which increases sunlight interception in the clusters (Bem et al., 2015). However, OTS effectively captures incident light, allowing for its better use by the plant photosynthetic apparatus (Scafidi et al., 2017). Therefore, vegetative canopy architecture resulting from the adopted training system and from the vigor provided by the rootstock shall determine the microclimate around the clusters. This, in turn, might influence transpiration rate, changing the water stress in the xylem, which might prevent the water flow to the phloem, changing turgor pressure gradient, and consequently, tissue turgidity. This condition shall affect COMP (Nikinmaa et al. 2012). High temperatures and solar radiation in the second half of the year in the Submedium São Francisco Valley stimulate cell metabolism, speeding maturation events, such as pectin solubilization and cell wall degradation. Consequently, lower COMP is expected due to berry softening (Ribeiro et al., 2012).

Regarding color attributes data, a* did not have normal distribution (Table 1), luminosity (L) was influenced by productive cycles (Table 3 ), and $b^{*}$ was affected by the interaction between training systems and rootstocks (Table 5). Attribute $a^{*}$ varied from 0.88 to 1.90 in grapes trained to VSP with both rootstocks and grapes trained to VSP and 'IAC 572 ' in the second half of 2017 , respectively, while values varied from 1.17 to 3.75 in grapes trained to OTS and rootstock 'IAC 572' and grapes trained to lyre and 'IAC 572', in cycle 2. Importantly, higher a* values were observed in cycle 2 in grapes trained to lyre (Table 1). Cycle 2 also provided berries with higher $L$ (Table 3 ). Values of $b^{*}$ were observed to be more negative in berries trained to OTS and grafted onto 'IAC 572' (Table 5). Color attributes in Vitis labrusca grapes are determined primarily by anthocyanin compounds (Leão et al., 2016), which predominantly affect the color of their derivatives. Color intensity in grape juice is related to positive $a^{*}$ values, corresponding to variations of red, and negative $b^{*}$ values, related to violet blue. Naturally, the anthocyanin coloration is affected by the replacement of hydroxyl and methoxyl groups in the molecule, so that increased numbers of hydroxyl groups tend to cause the coloring to become blueish and increased methoxyl groups increase the intensity of red (Delgado-Vargas et al., 2000). The exposure of both leaves and fruits to sunlight affects the expression of genes of UDP-Glucose: flavonoid 3-OGlucosiltransferase (Ufgt) enzyme (Downey et al., 2006). Also, accumulation of $V v m y b A 1$ mRNA might control the transcription of Ufgt genes and of other enzymes in the anthocyanin biosynthetic pathway, which are also affected by the leaf intensity in the canopy. Since red and violet blue pigmentations derive from anthocyanins, canopy architecture might affect the transcription of enzymes involved in the synthesis of these pigments, and consequently, of color attributes on the skin (Leão et al., 
2016). Therefore, more positive a* values in grapes trained to OTS are related to the higher interception of sunlight provided by the canopy architecture of these systems (Scafidi et al., 2017; Bem et al., 2015). The $a^{*}$ values observed in this study lie within the range mentioned by Ribeiro et al. (2012), with the same cultivar and in the same cultivation region. However, there was higher violet blue pigment in the present study. Titratable acidity (TA) was affected by training systems and production cycles (Table 3 ). Grapes harvested from plants trained to lyre had lower TA than those trained to OTS. According to Pastore et al. (2017), light does not affect the accumulation of malic acid and tartaric acid in grape tissues. Nevertheless, high temperature stimulates the degradation of these acids due to high respiratory rates. Hence, thermal increase due to higher exposure of the cluster to sunlight provided by canopy architecture of grapevines trained to lyre might explain the lower TA of berries from plants trellised to this training system. Accordingly, higher temperatures in the second half of 2018 might explain the lower TA recorded in berries harvested in this cycle. Soluble solid contents (SSC) were affected by the interaction between training systems, rootstocks, and production cycles (Table 6). Higher contents were observed in cycle 1 , except for grapes trained to VSP and 'IAC 572', which did not statistically differ between cycles. In both productive cycles, OTS associated to rootstock 'IAC 572' provided higher SSC: 26.6 -Brix in cycle 1, and 24.0 Brix in cycle 2. Total soluble sugar contents (TSS) were affected by the interaction between training systems and rootstocks, as well as training systems and production cycles (Tables 5 and 7). There was difference between rootstocks in grapevines trained to VSP and lyre, with higher values in plants grafted onto 'IAC 766' with the former,

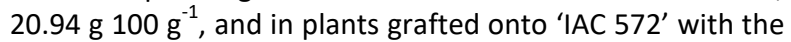

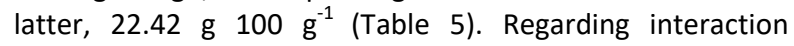
between training systems and productive cycle, lyre and OTS resulted in grapes with higher TSS in cycle 1 (Table 7). One aspect of utmost importance is the change caused to the microenvironment in the cluster zone, especially regarding sunlight (photosynthetically active radiation and red light/distant red ratio) provided by each training system. Wind speed, evaporation rate, temperature, and relative air humidity change due to the characteristics of the training system (Scafidi et al., 2017). High temperature and high incidence of solar radiation favor caused photosynthetic rates and carbohydrate accumulation to increase. This was occurred in grapes trained to lyre and OTS, which are systems with higher sunlight capture, increasing TSS (Rienth et al., 2014) as main constituents of soluble solids.

\section{Phenolic compounds and antioxidant activity}

Data of yellow flavonoids (FLAV) and total anthocyanin contents (ANT) in the skin as well as total extractable polyphenols content (TEP) in both skin and pulp did not have normal distribution. Higher variation in FLAV were observed

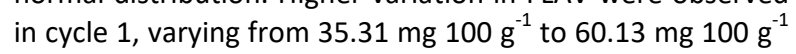
in grapevines trained to VSP with rootstock 'IAC 766' and OTS and 'IAC 766', respectively (Table 1). In cycle 2, FLAV varied from $26.44 \mathrm{mg} 100 \mathrm{~g}^{-1}$ to $38.11 \mathrm{mg} 100 \mathrm{~g}^{-1}$, in grapevines trained to lyre and grafted onto rootstock 'IAC 572 ' and treatment associated with OTS system grafted on 'IAC 572', respectively. It is worth noting that, the highest FLAV were found in grapevine berries trained to lyre and OTS in cycle 1 . The VSP system provided more stability in the accumulation of these compounds between production cycles. Sunlight induces the accumulation of flavonoids in berries (Downey et al., 2006), which is possibly related to increased expression of flavonol synthase genes (Pastore et al., 2017). In the present study, even though similar solar radiation indices were observed in both production cycles, there were differences between FLAV, indicating that other factors, either biotic or abiotic, affect the biosynthesis or degradation of this class of phenolic compounds. Similar to FLAV, the accumulation of ANT was higher in the cycle of the second half of 2017 , cycle 1 , with values varying from 235.74

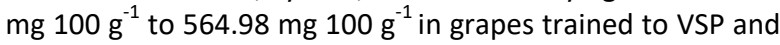
rootstock 'IAC 572' and those trained to OTS and grafted onto to 'IAC 766', respectively (Table 1 ). In second half of 2018 , cycle 2, values varied from $113.13 \mathrm{mg} 100 \mathrm{~g}^{-1}$ to

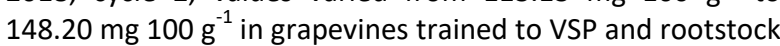
'IAC 766 ' and OTS on rootstock 'IAC 766', respectively. Increased phenolic compounds contents are related to the positive regulation of light on proteins involved in the phenylpropanoid biosynthesis pathway, namely, phenylalanine ammonia-lyase (Wang et al., 2015), corroborating with higher accumulation of anthocyanins in grapes trained to lyre and OTS when associated to rootstock 'IAC 766' (less vigorous than 'IAC 572') in cycle 2. This response is explained by the fact that OTS and lyre, in grapevines grafted onto 'IAC 766 ', enabled higher solar radiation capture, assuming that light conditions in the second half of the year are suitable for the biosynthesis of anthocyanins in grapevines trained to both mentioned systems. Importantly, the high temperature provided by higher solar radiation capture in lyre and OTS systems apparently does not induce a negative impact on anthocyanin accumulation, even though this condition is reportedly responsible for the degradation of these compounds (Movahed et al., 2016). According to Bem et al. (2015), vineyards trained to lyre have a higher accumulation of phenolic compounds, since this system promotes a moderate stress on the vineyard by exposing its foliage to radiation. In the present study, OTS system associated with rootstock 'IAC 766', caused higher ANT and FLAV in the second half of 2017 as it provided high interception of solar radiation in the vegetative canopy, and consequently, higher temperatures in the clusters. As there were no noticeable differences observed in climatic conditions between the cycles evaluated (Table 4), the higher accumulation of these compounds in cycle 1 can be explained by high variations in the synthesis and degradation rates of some of the most important compounds of berry quality and composition, even climatic factors, training system, and rootstock are similar (Downey et al., 2006). TEP varied from $132.53 \mathrm{mg}$ gallic acid $100 \mathrm{~g}^{-1}$ to $188.32 \mathrm{mg}$ gallic acid $100 \mathrm{~g}^{-1}$ in grapevines trained to OTS and grafted onto 'IAC 572' and in grapevines trained to VSP grafted onto 'IAC 766 ', in the second half of 2017 (Table 1). In cycle 2, contents varied from $157.31 \mathrm{mg}$ gallic acid $100 \mathrm{~g}^{-1}$, in crops trained to lyre with 'IAC 572', to $342.39 \mathrm{mg}$ galic acid $100 \mathrm{~g}^{-1}$, in OTS grafted onto 'IAC 766'. Unlike FLAV and ANT, the highest accumulation of TEP occurred in cycle 2 . The response to accumulation of TEP might be related to the diversity of compounds that encompass phenolics. Considering that some of them are more sensitive to exposure to climatic factors (such as solar radiation, temperature, and relative air humidity) than others, there is a differentiated influence on the activity of regulating enzymes (Wang et al., 2015; Pastore et al., 2017). 
Table 1. Cluster weight, skin color attribute $a^{*}$, yellow flavonoids, total anthocyanins, total extractable polyphenols content and antioxidant activity, determined by DPPH free radical capture method, in 'Isabel Precoce' grapes influenced by training systems, rootstocks and production cycles, in the Submedium São Francisco River Valley (mean \pm standard deviation) ${ }^{(1)}$

\begin{tabular}{|c|c|c|c|c|}
\hline \multirow{2}{*}{ Training system } & \multicolumn{2}{|c|}{ July to October, 2017} & \multicolumn{2}{|c|}{ July to October, 2018} \\
\hline & 'IAC 572' & 'IAC 766’ & 'IAC 572' & 'IAC 766’ \\
\hline & \multicolumn{4}{|c|}{ Cluster weight (g) } \\
\hline VSP & $50.83 \pm 8.09$ & $52.17 \pm 10.43$ & $116.12 \pm 5.77$ & $112.14 \pm 12.22$ \\
\hline Lyre & $58.49 \pm 8.02$ & $65.20 \pm 1.55$ & $118.81 \pm 5.29$ & $123.11 \pm 7.21$ \\
\hline OTS & $56.14 \pm 8.33$ & $81.09 \pm 6.20$ & $106.77 \pm 6.29$ & $106.36 \pm 9.69$ \\
\hline \multirow[t]{2}{*}{ CV $(\%)$} & 8.75 & & & \\
\hline & \multicolumn{4}{|c|}{ a* } \\
\hline VSP & $1.39 \pm 0.51$ & $0.98 \pm 0.10$ & $1.91 \pm 0,17$ & $2.02 \pm 0,34$ \\
\hline Lyre & $1.28 \pm 0.27$ & $1.21 \pm 0.32$ & $2.77 \pm 0.98$ & $2.23 \pm 0.53$ \\
\hline OTS & $1.05 \pm 0.11$ & $1.37 \pm 0.37$ & $1.64 \pm 0.47$ & $2.19 \pm 0.53$ \\
\hline \multirow[t]{2}{*}{ CV (\%) } & 27.13 & & & \\
\hline & \multicolumn{4}{|c|}{ Yellow flavonoids content $\left(\mathrm{mg} 100 \mathrm{~g}^{-1}\right)$} \\
\hline VSP & $42.88 \pm 4.01$ & $39.30 \pm 3.99$ & $36.93 \pm 1.04$ & $35.29 \pm 0.70$ \\
\hline Lyre & $52.76 \pm 5.87$ & $52.39 \pm 7.96$ & $27.75 \pm 1.31$ & $35.79 \pm 0.78$ \\
\hline OTS & $51.23 \pm 4.36$ & $53.27 \pm 6.86$ & $36.98 \pm 1.13$ & $33.89 \pm 1.03$ \\
\hline \multirow[t]{2}{*}{ CV $(\%)$} & 9.49 & & & \\
\hline & \multicolumn{4}{|c|}{ Total anthocyanins content (mg $\left.100 \mathrm{~g}^{-1}\right)$} \\
\hline VSP & $256.08 \pm 20.34$ & $283.20 \pm 31.81$ & $139.92 \pm 1.03$ & $115.17 \pm 2.04$ \\
\hline Lyre & $327.05 \pm 24.87$ & $300.11 \pm 29.42$ & $120.17 \pm 1.67$ & $146.02 \pm 2.18$ \\
\hline OTS & $492.17 \pm 58.52$ & $529.34 \pm 35.64$ & $124.09 \pm 2.38$ & $132.23 \pm 1.99$ \\
\hline \multirow[t]{2}{*}{ CV $(\%)$} & 11.00 & & & \\
\hline & \multicolumn{4}{|c|}{ Total extractable polyphenols content (mg of gallic acid $\left.100 \mathrm{~g}^{-1}\right)$} \\
\hline VSP & $166.91 \pm 7.32$ & $175.11 \pm 13.21$ & $261.01 \pm 4.71$ & $305.11 \pm 6.88$ \\
\hline Lyre & $145.31 \pm 9.28$ & $144.46 \pm 9.98$ & $160.89 \pm 3.58$ & $249.07 \pm 8.01$ \\
\hline OTS & $142.78 \pm 10.25$ & $146.81 \pm 4.74$ & $336.30 \pm 4.98$ & $330.34 \pm 12.05$ \\
\hline \multirow[t]{2}{*}{ CV (\%) } & 4.23 & & & \\
\hline & \multicolumn{4}{|c|}{ Antioxidant activity by DPPH (g g $\left.{ }^{-1} \mathrm{DPPH}\right)$} \\
\hline VSP & $8295 \pm 777$ & $7329 \pm 683$ & $13417 \pm 230$ & $10442 \pm 189$ \\
\hline Lyre & $9347 \pm 627$ & $9031 \pm 423$ & $14437 \pm 369$ & $10189 \pm 62$ \\
\hline OTS & $8579 \pm 897$ & $9399 \pm 419$ & $8506 \pm 269$ & $7503 \pm 340$ \\
\hline CV (\%) & 5.37 & & & \\
\hline
\end{tabular}

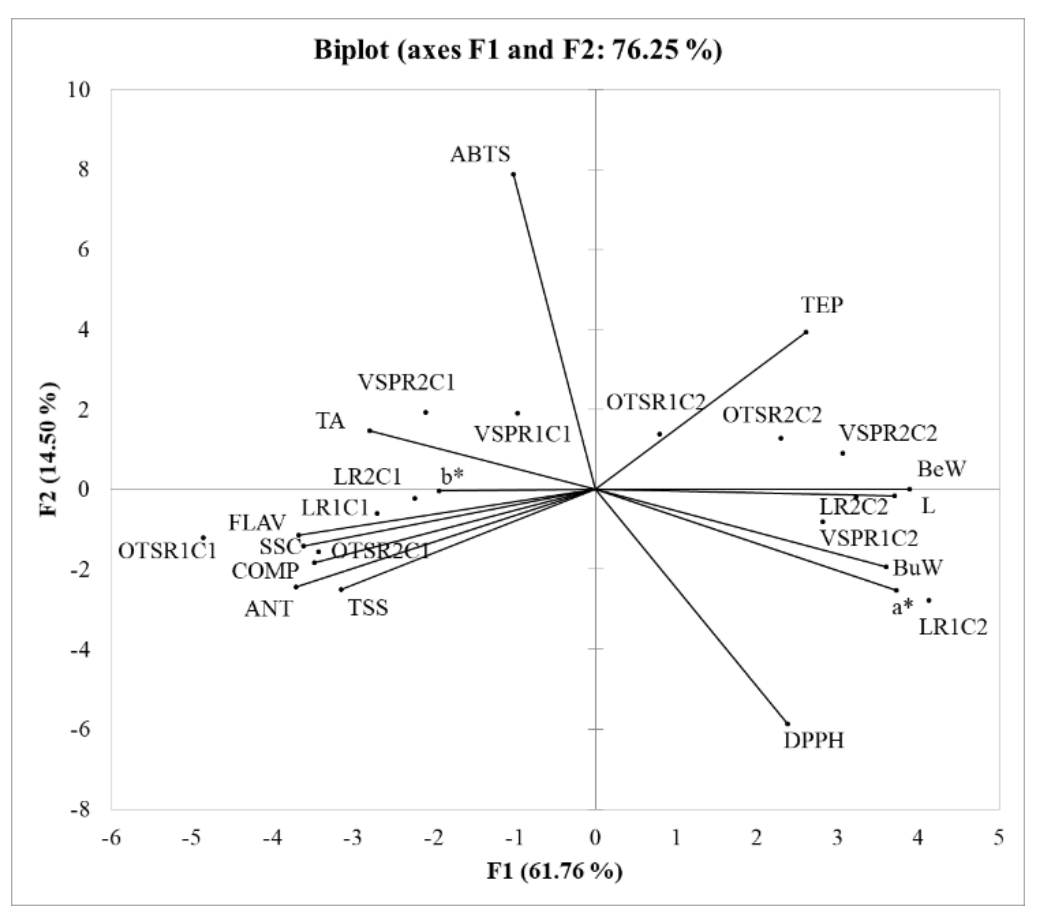

Fig 1. Principal component analysis of variables determinants of quality and antioxidant potential in 'Isabel Precoce' grapes under influence of training systems, rootstocks and production cycles in second half of the year, in Submedium of São Francisco Valley. 
Table 2. Berry weight in 'Isabel Precoce' grapes under the influence of rootstocks, in the Submedium São Francisco River Valley ${ }^{(1)}$.

\begin{tabular}{llc}
\hline Rootstock & Berry weight $(\mathrm{g})$ & $\mathrm{CV}(\%)$ \\
\hline 'IAC 572' & $2.32 \mathrm{~b}$ & \multirow{2}{*}{5.55} \\
'IAC 766' & $2.44 \mathrm{a}$ & \\
\hline \multicolumn{1}{|l|}{ Means followed by the same letter do not differ from each other using F test $(p \leq 0.05)}$.
\end{tabular}

Table 3. Berry weight, berry resistance to compression, luminosity (L) of skin color and titratable acidity in 'Isabel Precoce' grapes under the influence of training systems and or production cycles, in the Submedium São Francisco River Valley ${ }^{(1)}$

\begin{tabular}{|c|c|c|c|c|}
\hline \multirow{2}{*}{ Variable } & \multicolumn{3}{|c|}{ Training system } & \multirow{2}{*}{ CV (\%) } \\
\hline & VSP & Lyre & OTS & \\
\hline Berry weight (g) & $2.42 \mathrm{a}$ & $2.43 \mathrm{a}$ & $2.29 \mathrm{~b}$ & 5.55 \\
\hline Berry resistance to compression (N) & $6.21 b$ & $6.49 \mathrm{~b}$ & $7.28 \mathrm{a}$ & 7.99 \\
\hline \multirow[t]{3}{*}{$\begin{array}{l}\text { Titratable acidity } \\
\text { (g of tartaric acid } 100 \mathrm{~mL}^{-1} \text { ) }\end{array}$} & $0.65 a b$ & $0.58 \mathrm{~b}$ & $0.68 \mathrm{a}$ & 12.94 \\
\hline & \multicolumn{3}{|c|}{ Production cycle } & \\
\hline & \multicolumn{2}{|c|}{ July to October, 2017} & July to October, 2018 & \\
\hline Berry weight (g) & \multicolumn{2}{|c|}{$2.15 \mathrm{~b}$} & $2.62 \mathrm{a}$ & 5.55 \\
\hline Berry resistance to compression (N) & \multicolumn{2}{|l|}{$7.20 \mathrm{a}$} & $6.12 \mathrm{~b}$ & 7.99 \\
\hline $\mathrm{L}$ & \multicolumn{2}{|l|}{$27.44 \mathrm{~b}$} & $29.72 \mathrm{a}$ & 2.15 \\
\hline $\begin{array}{l}\text { Titratable acidity } \\
\text { (g of tartaric acid } 100 \mathrm{~mL}^{-1} \text { ) }\end{array}$ & \multicolumn{2}{|l|}{$0.68 a$} & $0.59 \mathrm{~b}$ & 12.94 \\
\hline
\end{tabular}

1) Means followed by the same letter in the row, comparing trellis system, do not differ from each other using Tukey's test $(p \leq 0.05)$. Means followed by the same letter in the row, comparing production cycles, do not differ from each other using $\mathrm{F}$ test $(p \leq 0.05)$.

Table 4. Mean monthly meteorological data of the Experimental Field of Bebedouro at Embrapa Semiárido, during production cycles from July 10, 2017 to October 30, 2017 and from July 2, 2018 to October 15, 2018, referring to the second halves of the year, when berry quality of 'Isabel Precoce' grapevines under influence of training systems and rootstocks were studied

\begin{tabular}{|c|c|c|c|c|c|c|c|c|}
\hline \multirow{2}{*}{ Period } & \multicolumn{3}{|l|}{$\mathrm{T}\left({ }^{\circ} \mathrm{C}\right)$} & \multirow{2}{*}{$\begin{array}{l}\mathrm{RH} \\
(\%)\end{array}$} & \multirow{2}{*}{$\begin{array}{c}\text { Rad. } \\
\left(\mathrm{MJ} \mathrm{m}^{-2} \mathrm{dia}^{-1}\right)\end{array}$} & \multirow{2}{*}{$\begin{array}{l}\text { Ws } \\
\left(\mathrm{m} \mathrm{s}^{-1}\right)\end{array}$} & \multirow{2}{*}{$\begin{array}{l}\text { Rainfall } \\
(\mathrm{mm})\end{array}$} & \multirow{2}{*}{$\begin{array}{l}\text { ET0 } \\
\left(\mathrm{mm} \mathrm{day}^{-1}\right)\end{array}$} \\
\hline & Mean & Max. & Min. & & & & & \\
\hline & \multicolumn{8}{|c|}{ Production cycle of July 10 to october 30,2017} \\
\hline $\mathrm{Jul} / 17$ & 22.9 & 28.4 & 17.6 & 69.0 & 15.1 & 3.2 & 4.7 & 4.4 \\
\hline Aug/17 & 25.1 & 31.8 & 19.1 & 64.7 & 21.5 & 2.7 & 0.6 & 5.7 \\
\hline Sep/17 & 24.1 & 30.7 & 18.5 & 68.7 & 20.2 & 3.5 & 11.9 & 6.0 \\
\hline Oct/17 & 27.9 & 34.9 & 21.7 & 65.6 & 25.3 & 3.5 & 0.0 & 7.6 \\
\hline \multirow[t]{2}{*}{ Average } & 25.0 & 31.4 & 19.2 & 67.0 & 20.5 & 3.2 & 4.3 & 5.9 \\
\hline & \multicolumn{8}{|c|}{ Production cycle of July 2 to october 15,2018} \\
\hline $\mathrm{Jul} / 18$ & 25.0 & 31.8 & 18.9 & 66.3 & 20.1 & 2.4 & 0.4 & 4.9 \\
\hline Aug/18 & 26.0 & 33.3 & 19.5 & 62.0 & 23.8 & 2.5 & 0.0 & 5.9 \\
\hline Sep/18 & 27.6 & 34.8 & 21.1 & 56.7 & 26.0 & 2.7 & 0.0 & 6.9 \\
\hline Oct/18 & 28.5 & 35.9 & 22.8 & 62.6 & 25.7 & 2.2 & 9.1 & 6.7 \\
\hline Average & 26.8 & 34.0 & 20.6 & 61.9 & 23.9 & 2.5 & 2.4 & 6.1 \\
\hline
\end{tabular}

Mean T = Mean temperature; T Max = Maximum temperature; T Min = Minimum temperature; RH = Relative humidity; Rad = Global solar radiation; Ws = Win speed at a 2.0 $\mathrm{m}$ height; Rainfall = Accumulated rainfall during the month; ETO= Reference evapotranspiration. Source: Agrometeorological Station of Bebedouro, Petrolina, Pernambuco State, Brazil (Embrapa Semiárido, 2017; Embrapa Semiárido, 2018).

Table 5. Skin color attribute $b^{*}$ and total soluble sugars content in 'Isabel Precoce' grapes under the influence of training systems and rootstocks, in the Submedium São Francisco River Valley ${ }^{(1)}$.

\begin{tabular}{|c|c|c|c|}
\hline \multirow{2}{*}{ Training system } & \multicolumn{2}{|l|}{ Rootstock } & \multirow{2}{*}{$\mathrm{CV}(\%)$} \\
\hline & 'IAC 572' & 'IAC 766' & \\
\hline & \multicolumn{2}{|l|}{$b^{*}$} & \\
\hline VSP & $-1.08 \mathrm{aA}$ & $-1.27 \mathrm{aA}$ & \\
\hline Lyre & $-1.21 \mathrm{aA}$ & $-1.39 \mathrm{aA}$ & 22.70 \\
\hline \multirow[t]{2}{*}{ OTS } & $-1.73 b B$ & $-1.39 \mathrm{aA}$ & \\
\hline & \multicolumn{2}{|c|}{ Total soluble sugars content $\left(\mathrm{g} 100 \mathrm{~g}^{-1}\right)$} & \\
\hline VSP & $19.84 \mathrm{bB}$ & $20.94 \mathrm{aA}$ & \\
\hline Lyre & $21.63 \mathrm{aA}$ & $21.26 \mathrm{aA}$ & 4.44 \\
\hline OTS & $22.42 \mathrm{aA}$ & $21.32 \mathrm{bA}$ & \\
\hline
\end{tabular}

${ }^{(1)}$ Means followed by the same lowercase letter in the row or uppercase letter in the column do not differ from each other in relation to rootstocks and training systems, respectively, using Tukey's test $(p \leq 0.05)$

Table 6. Soluble solids content (우ix) of 'Isabel Precoce' grapes under the influence of production cycles, training systems and rootstocks, in the Submedium São Francisco River Valley ${ }^{(1)}$

\begin{tabular}{|c|c|c|c|c|}
\hline \multirow{2}{*}{ Training system } & \multicolumn{2}{|c|}{ July to October, 2017} & \multicolumn{2}{|c|}{ July to October, 2018} \\
\hline & IAC 572 & IAC 766 & IAC 572 & IAC 766 \\
\hline VSP & $22.1 \mathrm{aCb}$ & $24.6 a \mathrm{Aa}$ & $22.1 \mathrm{aBa}$ & $22.0 \mathrm{bAa}$ \\
\hline Lyre & $24.6 \mathrm{aBa}$ & $23.8 a \mathrm{Aa}$ & $22.1 b \mathrm{Ba}$ & $21.7 b \mathrm{Aa}$ \\
\hline отS & $26.6 a \mathrm{Aa}$ & $25.2 a \mathrm{Ab}$ & $24.0 \mathrm{bAb}$ & $22.4 \mathrm{bAa}$ \\
\hline CV (\%) & 3.87 & & & \\
\hline
\end{tabular}

${ }^{(1)}$ Means followed by the same lowercase letter in italics in the column, comparing training systems associated to each rootstock and their interaction with production cycle, and means followed by the same uppercase letter, comparing rootstock associated to each training system and their interaction with production cycle, do not differ from each other using Tukey's test ( $p \leq 0.05)$. On the rows, mean values followed by the same lowercase letter in bold, comparing production cycles associated to each training system and their interaction with rootstocks, do not differ from each other using Tukey's test $(p \leq 0.05)$. 
Table 7. Total soluble sugars content and antioxidant activity, determined by $\mathrm{ABTS}^{\bullet+}$ free radical capture method, in 'Isabel Precoce' grapes influenced by training systems and production cycles, in the Submedium São Francisco River Valley ${ }^{(1)}$.

\begin{tabular}{|c|c|c|c|}
\hline Training system & July to October, 2017 & July to October, 2018 & CV (\%) \\
\hline & \multicolumn{2}{|c|}{ Total soluble sugars content $\left(\mathrm{g} 100 \mathrm{~g}^{-1}\right)$} & \\
\hline VSP & $20.31 \mathrm{aB}$ & 20.48 aA & \\
\hline Lyre & $22.81 \mathrm{aA}$ & $20.09 \mathrm{bA}$ & 4.44 \\
\hline \multirow[t]{2}{*}{ OTS } & $22.80 \mathrm{aA}$ & $20.94 \mathrm{bA}$ & \\
\hline & \multicolumn{2}{|c|}{ Antioxidant activity by $\mathrm{ABTS}^{\bullet+}$ method $\left(\mu \mathrm{M}\right.$ Trolox $\left.\mathrm{g}^{-1}\right)$} & \\
\hline VSP & $9.82 \mathrm{aA}$ & $8.33 \mathrm{bA}$ & \\
\hline Lyre & $8.46 \mathrm{aB}$ & $6.76 \mathrm{bB}$ & 7.90 \\
\hline OTS & $7.45 b c$ & $8.71 \mathrm{aA}$ & \\
\hline
\end{tabular}

1) Means followed by the same lowercase letter in the row or uppercase letter in the column do not differ from each other in relation to production cycles and training systems, respectively, using Tukey's test $(p \leq 0.05)$.

Table 8. Antioxidant activity, determined by $\mathrm{ABTS}^{\bullet+}$ free radical capture method, in $\mu \mathrm{M}$ Trolox g-1, in 'Isabel Precoce' grapes influenced by rootstocks and production cycles, in the Submedium São Francisco River Valley ${ }^{(1)}$.

\begin{tabular}{llll}
\hline Rootstock & July to October, 2017 & July to October, 2018 & CV (\%) \\
\hline 'IAC 572' & $8.49 \mathrm{aA}$ & $7.45 \mathrm{aB}$ & 7.90 \\
'IAC 766' & $8.65 \mathrm{aA}$ & $8.42 \mathrm{aA}$ & \\
\hline
\end{tabular}

${ }^{(1)}$ Means followed by the same lowercase letter in the row or uppercase letter in the column do not differ from each other in relation to production cycles and rootstocks, respectively, using Tukey's test $(p \leq 0.05)$.

Antioxidant activity (AA) calculated by ABTS was affected by the interactions between training system and productive cycle (Table 7) and between rootstock and productive cycle (Table 8). The AA in berries trained to VSP and lyre was higher in the second half of 2017, $9.82 \mu \mathrm{M}$ Trolox $\mathrm{g}^{-1}$ and $8.46 \mu \mathrm{M}$ Trolox $\mathrm{g}^{-1}$, respectively, while antioxidant activity was higher with OTS in the second half of 2018 (Table 6). Regarding the interaction between rootstocks and productive cycles, 'IAC 766 ' provided higher antioxidant activity in both cycles such as $8.65 \mu \mathrm{M}$ Trolox $\mathrm{g}^{-1}$, in cycle 1 , and $8.42 \mu \mathrm{M}$ Trolox ${ }^{-1}$, in cycle 2 (Table 8).

Data on AA by DPPH did not have a normal distribution. VSP associated to rootstock 'IAC 766 ' provided higher AA in grapes in the second half of 2017, with values ranging from $6646 \mathrm{~g} \mathrm{~g}^{-1}$ DPPH to $8012 \mathrm{~g} \mathrm{~g}^{-1}$ DPPH, (Table 1), while OTS associated to rootstock 'IAC 766' provided the highest AA in the second half of 2018 , with values ranging from $7163 \mathrm{~g} \mathrm{~g}^{-1}$ $\mathrm{DPPH}$ to $7843 \mathrm{~g} \mathrm{~g}^{-1} \mathrm{DPPH}$. It is worth noting that grapes trained to OTS had more stability in AA between productive cycles, with high activity in both. Grape yield, quality, and phenolic composition are sensitive to heat, especially in some development stages, such as flowering and ripening. The prolonged periods with temperatures higher than $30^{\circ} \mathrm{C}$ cause reduced photosynthesis and compromise fruit quality and composition (Movahed et al., 2016). During this study, a maximum temperature above $30{ }^{\circ} \mathrm{C}$ and solar radiation higher than $25 \mathrm{MJ} \mathrm{m}^{-2}$ day $^{-1}$ was observed on harvests of the second halves of the years (Table 4). Hence, the efficiency of each training system associated to a given rootstock in providing adequate exposure of berries to solar radiation and a microclimate that does not compromise grape quality as well as synthesis. The accumulation of phenolic compounds might explain the variation in the responses of treatments regarding each quality component evaluated. Therefore, it is not possible to ensure the stability of quality and phenolic composition parameters through harvests in the vineyard, even if canopy management practices are adjusted based on the adequate choice of training systems and rootstocks that provide canopy architecture through which clusters receive sufficient diffused light, and thus improve the microclimate protecting berries from excessive direct exposure to sunlight (Scafidi et al., 2017).

\section{Principal component analysis (PCA)}

According to PCA, components 1 and 2 explained $76.25 \%$ of the variation, ANT, FLAV, and SSC and TSS, as well as COMP were the variables that best contributed with the distinction between OTS associated to rootstock 'IAC 572' in cycle 1 (OTSR1C1), OTS associated to 'IAC 766' in cycle 1 (OTSR2C1), and lyre associated to rootstock 'IAC 572' in cycle 1 (LR1C1), as shown in Figure 1. TEP was the variable that best contributed positively with the distinction between OTS associated to 'IAC 572' in cycle 2 (OTSR1C2), OTS associated to 'IAC 766' in cycle 2 (OTSR2C2), and VSP associated to 'IAC $766^{\prime}$ in cycle 2 (VSPR1C2). AA determined using the $\mathrm{DPPH}^{\bullet+}$ radical capture method, along with $\mathrm{CW}$ and skin color attribute $a^{*}$, were the variables that best contributed with the distinction between lyre associated to 'IAC 572' in cycle 2 (LR1C2), lyre associated to 'IAC 766' in cycle 2 (LR2C2), and VSP associated to 'IAC 572' in cycle 2 (VSPR1C2). The components that were most affected by training systems and rootstocks ratify the influence of management on phenolic synthesis, according to canopy architecture. The adequate selection of both training system and rootstock for a given cultivation condition leads to the adequate use of solar radiation and helps to obtain a suitable microclimate that prevents such compounds from degrading (Hickey et al., 2018).

\section{Material and Methods}

\section{Plant material and treatments}

The experiment was conducted in a vineyard of Isabel Precoce cultivar, implemented in December 2015 in Petrolina, Pernambuco (09-09' S, 4022' W, $376 \mathrm{~m}$ of altitude, and $\mathrm{BSwh}$ climate), trellised to three training systems (OTS, lyre, and VSP, all with $3.0 \mathrm{~m} \times 1.0 \mathrm{~m}$ spacing), and grafted onto two rootstocks ('IAC 572' and 'IAC 766'). 
Production cycles in the second halves of two years (warmer season) were evaluated: from July 10, 2017 (production pruning) to October 30, 2017 (harvest); and from July 2, 2018 (production pruning) to October 15, 2018 (harvest).

Farming practices during the experiment followed the recommendations for viticulture in the Submedium São Francisco River Valley, based on plant and soil analysis and adopting a daily dripping irrigation, with irrigation rates varying according to meteorological data collected for each day in the experimental area. Meteorological data observed during this period are shown in Table 4.

Experiment design was randomized blocks with subsubplots through time. Treatments considered the plots represented by training systems, subplots corresponding to rootstocks, and sub-subplots corresponding to production cycles. Four replicates comprised of five plants were implemented. Ten clusters were collected from each experiment plot for analyses of quality components, phenolic composition, and antioxidant activity.

\section{Analysis of berry quality}

$\mathrm{CW}(\mathrm{g})$ and $\mathrm{BW}(\mathrm{g})$ were measured using a precision semianalytical scale (VI 2400, Acculab, Florida, USA). The values obtained corresponded to the mean weights of ten clusters and fifty fresh and healthy berries, sampled from clusters collected. To analyze COMP (N), the required strength to cause a $20 \%$ deformation of the initial volume was calculated using a digital texturometer (Extralab TA.XT.Plus, Stable Micro Systems, Surrey, UK) with a $\mathrm{P} / 75$ pressure plate. Twenty berries were used per plot for that purpose, evenly separated from clusters of each plot (Ribeiro et al., 2012). Berry skin color attributes $L, a^{*}$ and $b^{*}$ were measured in twenty berries collected from the upper, median, and lower regions of the ten clusters from each plot using a digital colorimeter (CR-400, Konika Minolta, Tokyo, Japan). SSC ('Brix) was determined using a digital refractometer with automatic temperature compensation (PAL-1 model, ATAGO, Tokyo, Japan), from juice extracted from grape pulp (AOAC, 2010). TSS (g $100 \mathrm{~g}^{-1}$ ) were determined using an anthron reactant, in a UV-Vis Spectrophotometer (Cary ${ }^{\circledast}$ 50, Varian, Melbourne, Australia), at $620 \mathrm{~nm}$ (Yemn and Willis, 1954). TA (g of tartaric acid $100 \mathrm{~mL}^{-1}$ ) was measured using a digital automatic titrater potentiometer (Titrino plus 848, Metrohm, Herisau, Switzerland).

\section{Analyses of phenolic compound contents and antioxidant activity}

Phenolic composition was evaluated using FLAV and ANT in grape skin (mg $100 \mathrm{~g}^{-1}$ ) and TEP in both skin and pulp (together). The two former chemical groups were extracted and determined following the method proposed by Francis (1982). FLAV and ANT were quantified using a Varian Cary ${ }^{\circledR}$ 50 UV-Vis Spectrophotometer, at $374 \mathrm{~nm}$ and $535 \mathrm{~nm}$, respectively. TEP ( $\mathrm{mg}$ of gallic acid $100 \mathrm{~g}^{-1}$ ) as well as total AA were determined from the ground skin and smashed pulp, using $50 \%$ methyl alcohol and $70 \%$ acetone as extracting solutions (Larrauri et al., 1997). TEP were determined with Folin-Ciocalteu reactant and $20 \%$ sodium carbonate, using Varian Cary ${ }^{\circledR} 50$ UV-Vis Spectrophotometer with readings at $700 \mathrm{~nm}$ (Larrauri et al., 1997). The AA were determined using the $\mathrm{ABTS}^{\bullet+}$, expressed in $\mu \mathrm{M}$ Trolox $\mathrm{g}^{-1}$, and $\mathrm{DPPH}^{\bullet}$, expressed in $\mathrm{g} \mathrm{g}^{-1} \mathrm{DPPH}$, free radical capture methods. The
$\mathrm{ABTS}^{\bullet+}$ method followed the procedure described by Miller et al. (1993), and adapted by Rufino et al. (2010) using Varian Cary ${ }^{\circledR} 50$ UV-Vis Spectrophotometer readings at 734 $\mathrm{nm}$. The AA determined using the $\mathrm{DPPH}^{\bullet}$ method followed Sánchez-Moreno et al. (1998), with adaptations suggested by Ruffino et al. (2010) and readings performed at $515 \mathrm{~nm}$, using the same equipment.

\section{Statistical analysis}

The normal distribution of data was evaluated using the Shapiro-Wilk test. Data that met normal distribution were submitted to an analysis of variance, checking the effects of plots, subplots, and sub-subplots, as well as possible interactions between them, comparing their mean values using Tukey's test $(p \leq 0.05)$. Data that did not show normal distribution and did not adjust to any transformation were shown with their mean values and standard deviations. Data were also submitted to PCA in order to evaluate the behavior of treatments according to the variables.

\section{Conclusions}

The high incidence of solar radiation and high temperature during the fruit maturation phase of grapes in July to October in successive years (in a tropical semi-arid climate), affect differentially berry quality and particularly phenolic composition. This can be reflected in the antioxidant activity. Plants trained to lyre and VSP systems had higher berry mass and lower resistance to compression in cycle of the second half of 2018. However, in the second half of 2017, lyre and VSP provided higher accumulation of total sugars and higher anthocyanin and yellow flavonoid contents, while grapes trained to VSP had higher antioxidant activity. The chemical composition of 'Isabel Precoce' grapes had variations even under similar climatic factors, training systems and rootstocks. It was not possible to ensure the stability of quality and phenolic composition in harvests of the same half of different years.

\section{Acknowledgments}

The authors are grateful for the financial support by the Brazilian Agricultural Research Corporation (Embrapa) Grant Number 02.13.06.005.00.00, and to Coordination of Higher Education (CAPES) for the scholarship for the first author. This article is a requirement for the D. Sc. title by RRC at the UFPB, Agronomy Postgraduate Program - Areia, Paraiba - Brazil.

\section{References}

Association of Official Agricultural Chemists - AOAC (2010) Official methods of analysis of the Association of the Agricultural Chemists. 18th ed. Gaithersburg: AOAC.

Bascuñán-Godoy L, Franck N, Zamorano D, Sanhueza C, Carvajal DE, Ibacache A (2017) Rootstock effect on irrigated grapevine yield under arid climate conditions are explained by changes in traits related to light absorption of the scion. Sci Hortic. 218(1): 284-292.

Bem BP, Bogo A, Everhart S, Casa RT, Gonçalves MJ, Filho JLM, Cunha IC (2015) Effect of Y-trellis and VSP training systems on downy mildew and botrytis bunch rot of grape in highlands of southern Brazil. Sci Hortic. 185(30): 162166. 
Camm EL, Towers GHN (1973) Phenyalanine ammonia lyase. Phytochem. 12(5): 961-973.

Delgado-Vargas F, Jiménez AR, Parede-López O (2000) Natural pigments: carotenoids, anthocyanins, and betalains - characteristics, biosynthesis, processing, and stability. Crit Rev Food Sci Nutr. 40(3): 173-289.

Downey MO, Dokoozlian NK, Krstic MP (2006) Cultural practice and environmental impacts on the flavonoid composition of grapes and wine: a review of recent research. Am J Enol Viticult. 57(3): 257-268.

Duchêne E (2016) How can grapevine genetics contribute to the adaptation to climate change? OENO One 50(3): 113124.

Embrapa Semiárido. Dados meteorológicos (2017) Available in:<http://www.cpatsa.embrapa.br:8080/index.php?op=d adosmet>. Acess in: May 11, 2018.

Embrapa Semiárido. Dados meteorológicos (2018) Available in:<http://www.cpatsa.embrapa.br:8080/index.php?op=d adosmet>. Acess in: May 01, 2019.

Francis FJ (1982) Analysis of anthocyanins. In: Markakis P. (ed) Anthocyanins as food colors, $1^{\text {a }}$ ed. Academic Press, New York. 7.

Hickey CC, Kwasniewski MT, Wolf TK (2018) Leaf removal effects on Cabernet Franc and Petit Verdot. II. Grape carotenoids, phenolics, and wine sensory analysis. Am J Enol Viticult. 69(3): 231-246.

Jeong ST, Goto-Yamamoto N, Kobayashi S, Esaka M (2004) Effects of plant hormones and shading on the accumulation of anthocyanins and the expression of anthocyanin biosynthetic genes in grape berry skins. Plant Sci. 167, 247-252.

Larrauri JA, Rupérez P, Saura-Calixto F (1997) Effect of drying temperature on the stability of polyphenols and antioxidant activity of red grape pomace peels. J Agric Food Chem. 45(4): 1390-1393.

Leão PCS, Nunes BTG, Lima MAC (2016) Canopy management effects on 'Syrah' grapevines under tropical semi-arid conditions. Sci Agric. 73(3): 209-216.

Leão PCS, Rego JIS, Nascimento JHB, Souza EMC (2018) Yield and physicochemical characteristics of 'BRS Magna' and 'Isabel Precoce' grapes influenced by pruning in the São Francisco river valley. Cienc Rural. 48(6): e20170463.

Miele A, Rizzon LA (2017) Rootstock-scion interaction: 1. Effect on the yield components of Cabernet Sauvignon grapevine. Rev Bras Frutic. 39(1): e-434.

Miller NJ, Diplock AT, Rice-Evans C, Davies MJ, Gopinathan V, Milner A (1993) A novel method for measuring antioxidant capacity and its application to monitoring the antioxidant status in premature neonates. Clin Sci. 84(4): 407-412.
Movahed N, Pastore C, Cellini A, Allegro G, Valentini G, Zenoni S, Cavallini E, D'Incà E, Tornielli GB, Filippetti, I (2016) The grapevine VviPrx31 peroxidase as a candidate gene involved in anthocyanin degradation in ripening berries under high temperature. J Plant Res. 129(3): 513526.

Nikinmaa E, Hölttä T, Hari P, Kolari P, Mäkelä A, Sevanto S, Vesala T (2012) Assimilate transport in phloem sets conditions for leaf gas exchange. Plant Cell Environ. 36(3): 655-669.

Pastore C, Allegro G, Valentini G, Muzzi E, Filippetti I (2017) Anthocyanin and flavonol composition response to veraison leaf removal on Cabernet Sauvignon, Nero d'Avola, Raboso Piave and Sangiovese Vitis vinifera L. cultivars. Sci Horticult. 218(1): 147-155

Ribeiro TP, Lima MAC, Alves RE (2012) Maturação e qualidade de uvas para suco em condições tropicais, nos primeiros ciclos de produção. Pesq Agropec Bras. 47(8): 1057-1065.

Rienth M, Torregrosa L, Luchaire N, Chatbanyong $R$, Lecourieux D, Kelly MT, Romieu C (2014) Day and night heat stress trigger different transcriptomic responses in green and ripening grapevine (Vitis vinifera) fruit. BMC Plant Biol. 14(108): 118-125.

Rufino MSM, Alves RE, Brito ES, Pérez-Jiménez J, SauraCalixto F, Mancini-Filho J (2010) Bioactive compounds and antioxidant capacities of 18 non-traditional tropical fruits from Brazil. Food Chem. 121(4): 996-1002.

Sánchez-Moreno C, Larrauri JA, Saura-Calixto F (1998) A procedure to measure the antiradical efficiency of polyphenols. J Sci Food Agric. 76(2): 270-276.

Scafidi P, Barbagallo MG, Pisciotta A, Mazza M, Downey MO (2017) Defoliation of two-wire vertical trellis: effect on grape quality. New Zeal J Crop Hort. 46(1): 18-38.

Silva MJR, Paiva APM, Pimentel Junior A, Sánchez CAPC, Callili D, Moura MF, Leonel S, Tecchio MA (2018) Yield performance of new juice grape varieties grafted onto different rootstocks under tropical conditions. Sci Hortic. 241(18): 194-200.

Souza CR, Mota RV, França DVC, Pimentel RMA, Regina MA (2015) Cabernet Sauvignon grapevine grafted onto rootstocks during the autumn-winter season in southeastern Brazilian. Sci Agric. 72(2): 138-146.

Wang J, Ma L, Xi H, Wang L, Li S (2015) Resveratrol synthesis under natural conditions and after UV-C irradiation in berry skin is associated with berry development stages in 'Beihong' (V. vinifera x V. amurensis). Food Chem. 168(1): 430-438.

Yemn EW, Willis AJ (1954) The estimation of carbohydrate in plant extracts by anthrone. Biochem J. 57(3): 504-514. 